\title{
Exposure as Collected Planned Time Point
} Name

National Cancer Institute

\section{Source}

National Cancer Institute. Exposure as Collected Planned Time Point Name. NCI

Thesaurus. Code C117501.

The literal identifier of a planned point in time for exposure collection. 